\title{
The effect of global warming on beef production in developing countries of the southern hemisphere
}

\author{
M. M. Scholtz ${ }^{1,2^{*}}$, C. McManus ${ }^{3,4}$, K-J. Leeuw ${ }^{1}$, H. Louvandini ${ }^{5}$, L. Seixas ${ }^{3}$, C. B. de Melo ${ }^{3,6}$, \\ A. Theunissen ${ }^{7}$, F. W. C. Neser ${ }^{2}$

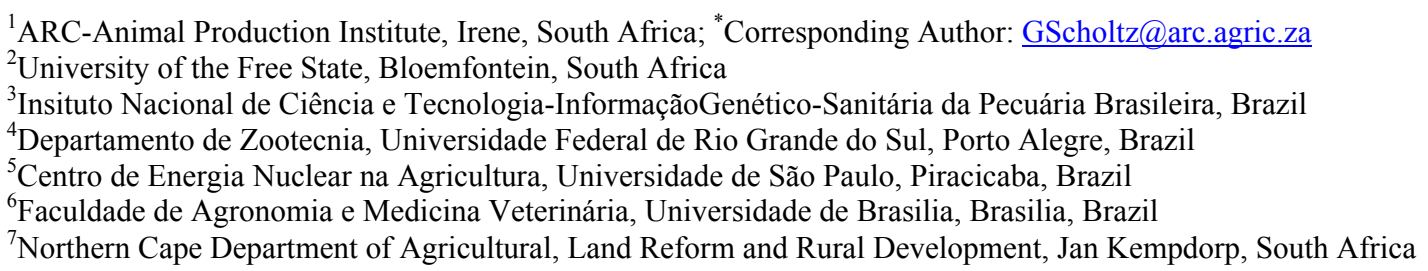

Received 21 November 2012; revised 20 December 2012; accepted 5 January 2013

\section{ABSTRACT}

Developing countries from the southern hemisphere will be confronted by the same beef production challenges caused by global warming, because these countries are at the same geographical positions in southern latitudes. Global warming is expected to have a more extreme effect on the southern hemisphere than on other continents and will have a negative effect on the beef production environments in these countries. The negative effects will include high ambient temperatures, nutritional stress and altered patterns of animal diseases. Heat stress in beef cattle on veld/savannah is expected to increase as a result of changing weather patterns on a global and regional scale. This may negatively influence food production from beef cattle for the human food chain. Negative effects of increased temperatures and thus heat stress can include lower reproductive rates and weaning weights. The effect of heat stress can be partly addressed by nutritional strategies, such as replacing rapid fermentable carbohydrates with saturated fatty acids and the feeding of more by-pass protein and dietary electrolytes. Global warming will also alter the distribution pattern of animal diseases and the vectors of some of these diseases. This may even include the spread to South American countries. Likewise the nutritional value of natural pastures may be influenced. The effect of global warming on the quality of pastures will depend on whether the global warming is a result of increased carbon dioxide levels or not. An improved understanding of the adaptation of beef cattle to their production environments is important, but adaptation is complex and thus difficult to measure. Fortunately, several proxy-indicators for adaptation such as reproductive, production and health traits are available. The selection of animals and genotypes that are better adapted to the production system, including heat stress, is possible and should be persuade to ensure sustainable beef production in hotter climates.

Keywords: Adaptation; Animal diseases; Heat Stress; Mitigation Strategies; Nutritional Stress

\section{INTRODUCTION}

Developing countries from the southern hemisphere (Africa south of the equator and Latin America) are confronted by many of the same socio-economic and beef production challenges. Added to this, is the fact that these countries are at the same geographical positions in the southern cone. The consequent similarities in climate and agricultural conditions mean that there are many areas of similar interest and concern regarding beef cattle production.

This paper aims to discuss the effect of global warming on beef production in the developing countries of the southern hemisphere and the challenges posed by global warming and the adaptation of genetic resources to production environments. Climate change is already affecting food security (food availability, food accessibility, food utilization and food systems stability) on a global level [1]. People living in fragile ecosystems (i.e. semiarid landscapes) are most at risk. Despite current efforts, changes in the climate will continue to occur [2]. Adaptation and mitigation strategies should therefore be developed at local and specific levels [1]. 
Climate change is perceived as a major threat to the survival of many species and ecosystems and the financial sustainability of pastoral systems in various parts of the world, especially in developing countries [3]. Recent economic studies have suggested that severe losses will occur if the current management systems are not modified in the face of climate change [4]. Therefore, there is great interest in understanding how domestic animals respond to climate stressors. Most of these studies were conducted in developed countries and have provided knowledge about the differences between the genotypes and the impact of environmental stress on the production, reproduction and animal health. However, little is known about the adaptation of animals to rapidly changing weather conditions, especially in developing countries, where the stressors are different and the intensity of expected change is greater [5]. Furthermore, there is a lack of information about the impacts of environmental stress on the wide variety of breeds used for food production [6].

Heat stress is a major factor involved in reducing productivity and animal development. If animals experience thermal discomfort, they seek ways to lose heat and this involves a series of adaptations of the respiratory, circulatory, excretory, endocrine and nervous systems. These characteristics of adaptation can determine the tolerance of each breed to its environment [7]. The coordination of all these systems to maintain the productive potential under thermal stress varies between species, breeds and individuals and within the same breed [8].

Changes in weather conditions can result in the redistribution of animals within or between regions, changes in the criteria for choice of species used (buffalo to cattle, sheep or goats), changes in genotype or breed (use of breeds that can maintain production in adverse conditions) and the environment (environmental protection or mitigation). The lack of information on tolerance to heat in different breeds is already perceived as a major constraint to production in Africa [9]. Studies on animal production in many countries have shown that there will be a need to replace breeds and species in production systems over the next 30 years due to changes in the environment and the market demands [10-12].

Increases in global temperatures over the last century are indicated as between $0.74^{\circ} \mathrm{C}$ [1] and $0.8^{\circ} \mathrm{C}$ [2] with an expected rise of up to $3^{\circ} \mathrm{C}$ in this century. The rise in average global temperature predicted for this century may even have to be adjusted upwards [2-3]. The anticipated global warming will change the southern hemisphere environments and vegetation, and in Africa the grazing capacity in some areas is expected to decline [15]. It is predicted that in South Africa the interior temperature will rise by $2^{\circ} \mathrm{C}$ to $3^{\circ} \mathrm{C}$ by 2050 [13]. For Brazil an expected increase of $5^{\circ} \mathrm{C}$ in air temperatures is predicted [14], which may lead to a decrease in pasture ca- pacity by up to approximately $50 \%$, which will be devastating.

Animal production is affected by climate in four major ways: 1) changes in livestock feed-grain availability and price; 2) livestock pastures and forage crop production and quality; 3) distribution of livestock diseases, disease vectors and parasites; and 4) direct effect of weather and extreme events on animal health, growth and reproduction [15-17].

Tropical and subtropical climates have both direct and indirect effects on livestock. Factors such as temperature, solar radiation, humidity and wind all have direct effects on animals, whereas factors such as digestibility of feed, intake, quality and quantity of grazing, pests and diseases (which are themselves directly influenced by climate change) all have indirect effects on animals. It is predicted that climate change will have a more extreme effect on the African continent than on any other continent.

\section{EFFECT OF AMBIENT TEMPERATURE}

The main environmental factors affecting animal production are the ambient temperature, humidity, solar radiation and wind [18]. In tropical regions, characterized by high levels of solar radiation and temperature, heat stress is a major factor limiting the development and production of animals. In the tropics and subtropics temperatures frequently rise above the comfort zone and it is therefore important that livestock are adapted to these higher temperatures [19] or management strategies are in place that can mitigate heat stress. High temperatures and solar radiation decrease feed intake in order for animals to reduce digestive heat production, and reduce grazing time (animals do not graze in hot midday hours), whereas sweating and water intake increases.

Besides environmental factors, the animal's response to heat stress depends on the breed, body size, production level and the degree of exposure to the stressor, and composes three phases, viz. the recognition of the threat to homeostasis or welfare, the response to stress and the consequences of stress. Some factors such as previous experience, genetics, age, sex, condition and physiological shape have an influence on the nature of the animal's biological response to the stressor [20,21]. Other factors involved in thermal comfort include the external coat of the animal (thickness, structure, thermo isolation, absorption and reflectivity) and body traits (shape, size and superficial area) [22,23].

\subsection{Heat Stress as a Result of Ambient Temperature}

Livestock in tropical and sub-tropical areas can be under heat stress during certain periods of the year or year round [24]. Animals that are under heat stress show a 
decrease in their production potential with devastating economic consequences to global animal agriculture [25]. With the expected increase in global temperatures and higher increases in certain regions, more areas will become arid with increasingly erratic weather conditions [13]. This will result in longer periods where livestock will experience heat stress.

In any production system, regardless of its purpose (dairy, beef), it is important that the animals are within their thermal comfort zone. This comfort zone, which varies among species, breeds and individual animals, comprise an upper critical (TCS) and lower critical (TCI) temperature, between which homeothermy is achieved with the minimum use of thermoregulatory mechanisms [26]. Temperatures above TCS or below the TCI trigger physiological and behavioral reactions and can, in extreme cases, cause death through hypothermia or hyperthermia, respectively. Knowledge of these comfort zones is of crucial importance so that producers can take steps to minimize the harmful effects and allow for optimum production.

Heat stress in livestock can be defined as a physiological condition in which the core body temperature is higher than the normal activity range. Core body temperature is the result of total heat load (internal heat production and environmental heat) minus the ability of the animal to dissipate heat from the body. If the heat load is above the animal's heat dissipation capability, the animal will respond to it through behavioral and physiological changes [25]. Heat stress can occur when temperatures are above $25^{\circ} \mathrm{C}$ for dairy cattle, when combined with high humidity, low air flow and direct sun light [27-28]. In beef cattle the threshold temperature above which dry matter intake is adversely affected is $30^{\circ} \mathrm{C}$ with a relative humidity of below $80 \%$, and if the relative humidity is above $80 \%$ the threshold temperature drops to $27^{\circ} \mathrm{C}$ [28].

Heat stress exerts several deleterious effects on the animal in an attempt to reduce the heat stress and to maintain homeothermy. The immediate reaction to increased heat load is increased respiration rates, decreased feed intake and increased water intake [22,23]. Further consequences are increased blood flow to the skin surface, reduced metabolic rate and altered water metabolism [29]. Panting can also result in both respiratory alkalosis and metabolic acidosis [30]. Cows exposed to acute heat stress (24 - 36 hours) have shown a reduction in milk yield and lactose content, but increased levels of protein and fat [31].

Among the factors that change the magnitude of an animal's response to thermal stress is the type of diet and breed [32]. Changes in diet ingredients that promote lower calorie increments, such as fats and grains, are essential to mitigate the negative effects of heat on production. Within the same breed, and even between breeds, the maintenance of body temperature is determined by heritable characteristics, such as the ability to sweat, low resistance to heat stress, as well as the structure and coloration of the tissue [33]. Thus, genetic characteristics can play an important role in tolerance to heat by animals [34]. The ability to maintain body temperature is critical as the animal will lose less energy to maintain thermal equilibrium, allowing for higher production, whether it is meat, wool or milk.

Protective characteristics depend on the morphology of the skin (color, thickness, sweat glands, etc.) and hair coat (especially the hair coat thickness, density, diameter and length of the hair as well as their inclination with respect to skin surface), which determine the animal's heat exchange with the environment through radiation, convection, conduction and evaporation [35]. It has also been shown that size, shape and surface area are important for the morphological heat balance [36].

The direct consequences of heat stress on animal production can be severe and is generally thought to be a response to the reduced feed intake by the affected cattle and it is claimed that the extent of the depression corresponds directly to the level of the stress $[37,38]$. The appetite of animals is influenced by direct regulation from the heat regulation centers, interference by high respiration rate and behavior changes directed toward decreased heat production. However, the size and age of the animal are also contributing factors.

The effects of heat stress are higher in cattle than in other ruminants due to their higher metabolic rate, and poorly developed water retention in the kidney and gut [25]. With an increased water intake as a mechanism to cope with heat stress, and more water expelled through sweating and panting, the body's water content and mineral concentrations can be disturbed. The reduced feed intake further compounds the problem, as energy intake drops and energy expenditure increases to achieve euthermia.

Beef cattle can particularly be vulnerable to extreme environmental conditions and to rapid changes therein [25]. Fat cattle with a lot of hair and dark coat are very sensitive to heat [3]. Cattle can, within limits, adapt to environmental challenges to minimize adverse consequences. However, at temperatures above $25^{\circ} \mathrm{C}$ feed intake drops [28]. Environments characterized by high temperatures and humidity will result in a reduction in the productivity of animals [32,39], and will thus have a financial impact on the cattle industry [40].

The level of ambient temperature thus affects production traits in cattle such as growth rate, milk production, milk composition (solids, milk fat, ratios of fatty acids, lactose, pantothenic acid, ascorbic acid and riboflavin) and reproduction in both male (gametogenesis and libido) and female (estrus, ovulation, fertilization, implantation, 
embryo survival, gestation length and mothering ability) animals directly $[37,41,42]$.

Milk yield is very sensitive to increased temperatures, with measurable declines in yield occurring in high producing cows at $24^{\circ} \mathrm{C}$. A decline in milk yield is predominantly the result of heat induced depression in feed intake [37]. However, it is also reported that reduction in feed intake only accounted for $35 \%$ of the reduction in milk production in mid-lactation cows [25]. Hormonal changes that occur in response to heat stress can also play an integral role in the reduced production [29].

Heat stress reduces reproductive abilities in both genders $[25,42]$. The effect of heat stress on summer fertility may result in a $20 \%$ to $27 \%$ drop in conception rates [43-45]. Furthermore, heat stress may lead to impaired embryo development and even embryo deaths. Sperm quality was also negatively affected by elevated ambient temperatures, i.e. reduced motility percentage, reduced sperm output and increased percentage of abnormal sperm and aged sperm [46].

Rising temperatures result in decreased activity of the thyroid gland and the output of gonadotropin that leads to inadequate estrogen or progesterone production. The pituitary gland also affects heat balance through the shifting of electrolytes during the mobilization of water for evaporation from the body [37].

While ambient temperatures above $29^{\circ} \mathrm{C}$ impair spermatogenesis and the quality of semen in bulls, the breeding of cows is only successful when their body temperatures are less than $39^{\circ} \mathrm{C}$ [37]. There is however differences between breeds in their thermoregulatory ability that can be exploited [37,47].

Genotype by environmental interaction and epigenetics affect some traits and can give an impression of acclimatization in animals. However, acclimatization has varying penalties on productivity [47]. For instance, in Brown Swiss cattle which were reared at two temperatures (cool and hot) and then shifted to a hotter environment, the group reared at hot temperatures showed less response to thermal stress than animals reared under cool conditions [37]. However, this group had similar impaired feed intake and growth rate as those animals reared at cool temperatures.

The classic genotype $\mathrm{x}$ environment research done at the Tropical Cattle Research Centre, Rockhampton in the seventies on Brahman and Brahman $\times$ Bos taurus cattle [48] as well as the work done in contrasting environments on Hereford cattle [49] clearly shows the effects of temperature on animal performance. These results stress the importance of adaptation to the production environment. Genotype by environmental interaction will become even more important as the environment changes or varies due to global warming. The implication of this is the better utilization of adaptive breeds. It is well do- cumented that Bos indicus cattle are better adapted to tropical environments than Bos taurus cattle $[48,50]$. The same argument could be followed to include the tropically adapted taurine breeds of Africa, Latin America and the Caribbean in this group. These breeds, or composite breeds derived from them, could eventually replace the less adapted Bos taurus types in the harsher production environments that are predicted for the future.

Crossbreeding to exploit heterosis under harsh environments is often used to counter genotype $\times$ environmental interaction and heterosis is generally larger under severe environments [51]. The production performance of F1 Brahman $\times$ British cows demonstrates that significant production benefits can be obtained from crossbreeding in most environments [52]. Depending on the environment, between $25 \%$ and $75 \%$ "adaptive genes" are required with up to $100 \%$ in the most severe environments [52]. These genes can be derived from Bos indicus and tropically adapted taurine breeds as well as their derivatives $[53,54]$. For the most severe environments a combination of Bos indicus and adaptive taurine breeds can be used to optimize heterosis and productivity [51]. The effect of the environment on the performance of various genotypes as well as the need for assessing the genotypes in the environment of interest should be emphasized [54].

\subsection{Nutritional Stress as a Result of Ambient Temperature}

The reduced feed intake as a result of heat stress will cause the animal to go into a negative energy balance and reduced intake of minerals. The uptake of nutrients in heat stressed animals is diminished by reduced ability of the rumen to absorb nutrients as more blood flows to the skin for cooling purposes [24,29]. This can affect rumen health as less feed is consumed, less saliva enters the rumen, volatile fatty acids (VFA) build up due to low absorption (decrease in ruminal $\mathrm{pH}$ ), combined with low levels of $\mathrm{HCO}_{3}^{-}$(carbonate) in the saliva, making cattle more susceptible to rumen acidosis [30]. However, it was also reported that there is no difference in VFA concentrations between temperature treatments and that there was even a reduction in VFA's in cattle subjected to heat stress [24].

Research has shown a depression in efficiency of feed utilization with lowered intake because a greater proportion of the energy consumed goes for maintenance requirements [36] and more energy is used for thermoregulatory processes [28].

In periods of heat stress, when feed intake decline and demands of lactation increase, an increased dietary mineral concentration is required [29]. Potassium (K) is the primary cation occurring in bovine sweat and its concentration in sweat increases during hot climate conditions 
[55]. During hot temperatures the absorption of macro minerals, including Calcium (Ca) Phosphate (P) and Potassium $(\mathrm{K})$, declines [56]. Dietary cation-anion differences can alter dry matter intake of beefs cows on rangelands [57]. It has also been reported that finishing steers maximized their gain and intake when fed diets that had a positive dietary electrolyte balance $(15 \mathrm{mEq} .100 \mathrm{~g}$ of DM) [56]. In this research [58] no consideration of temperature was taken into account and may explain why no differences on day 84 in plasma parameters were found. Positive results on production in cattle (dairy cows in hot weather) have been reported where potassium or sodium bicarbonate have been used as additives to increase the cation levels in rations $[25,59,60]$.

\subsection{Mitigation Strategies to Heat Stress}

Management approaches may reduce the effects of increased temperature, and may include mechanical cooling such as forced ventilation, water sprayers and shading [27]. However, these are difficult to apply to free grazing cattle and offer limited relief on a short term basis. With the increasing cost of energy, these methods might become uneconomical. Where temperatures rise above the upper critical threshold, which may occur more frequently and will probably happen as a result of climate change, the need for long term viable alternatives like breeding and changing the nutritional approaches may become more pressing.

Nutrition has an important role to play in the mitigation of heat stress effects. Cattle that experience heat stress will reduce intake in order to lower metabolic heat load. Therefore cattle will require alterative supplements, especially minerals such as potassium and sodium to counteract losses in cation ( $\mathrm{K}^{+}$through sweating), anion $\left(\mathrm{Cl}^{-}\right.$through respiration) and gasses $\left(\mathrm{CO}_{2}\right.$ through lungs); as well as reduced buffering in the rumen (less saliva into rumen) caused by less bicarbonate in the rumen, but more in the blood and mobilized in the kidneys. Furthermore, energy provision with sources such as maize, to counteract the lower intakes, may exacerbate the problem due to increased heat load through the digestion of the energy source. Alternatively, the replacement of rapid fermentable carbohydrates, such as maize, with saturated fatty acids has shown to reduce rectal temperatures and increase milk yield for mid lactation dairy cows [61]. The higher ammonia levels in the rumen due to reduced carbohydrate levels during periods of heat stress make it important that levels of rumen degradable protein and soluble nitrogen sources are limited in cattle feeds. Feeding more by-pass protein during hot climatic conditions can result in higher production [29].

Dietary electrolyte balance has the capacity to alter intake of beef cows and can improve feedlot performance. Although this principle is well established in the dairy industry, data on beef cattle production systems are limited [62] with no nutritional strategies to mitigate heat stress conditions [63]. There is some discussion on electrolyte balance in beef cows and feedlot cattle, but without the effect of climate $[57,58]$. Most work on cationanion levels were done in metabolic chambers [24] and/ or for short periods of time with short adaptation periods. Where measurements were taken over longer periods, constant levels of cation-anion were provided without consideration of climate $[57,58]$. There is a need to adapt the supplementary feeding management of beef cattle in temperatures above the thermal comfort limit in order to reduce losses in performance.

The measurement of heat tolerance on a large scale in animals is limited by the time required to do traditional testing [64], since animals are affected by several factors such as their level of production and type of food and the environmental conditions that change throughout the day. However, the selection of animals that adapt better to the production system, including heat stress, is still necessary to enable the sustainability of beef production systems in hotter climates.

\section{ALTERED PATTERNS OF ANIMAL DISEASES}

Altered patterns of diseases in animals are a significant and permanent threat as a result of climate change. This may include 1) the emergence of new diseases and 2) a change in the prevalence of existing diseases, particularly those spread by biting insects. A wider geographic distribution of known vectors and/or the recruitment of new strains to the vector pool could result in infections spreading to more and potentially new species of hosts [65]. Changes in climate will influence arthropod vectors, their life cycles and life histories, resulting in changes in both vector and pathogen distribution and changes in the ability of arthropods to transmit pathogens [66]. Therefore animals will be exposed to different parasites and/or diseases, as indicated by the predicted change in the distribution of, for example, the Tsetse fly in Africa [16]; putting an even greater pressure on production and the survival of livestock breeds.

The OIE Scientific Commission has therefore concluded that climate changes are likely to be an important factor in determining the spread of some diseases, especially those that are vector-borne. The two most mentioned emerging and re-emerging cattle diseases in a recent OIE survey are Catarrhal fever (Bluetongue) and Rift Valley fever [67].

Bluetongue is an infectious, non-contagious disease of wild and domestic ruminants, and has considerable economic impact partly due to direct losses from death and reduced production in affected livestock but, more importantly, because of the restrictions on international trade 
in animals and animal germ plasm between Blue-tongue virus infected and non-infected areas [68,69]. The global distribution of Bluetongue virus infection changed drastically in recent years [70,71], and climate change may be partly responsible for this profound change in the global distribution of the Bluetongue virus [70,72]. Studies have demonstrated that the vectors of the disease are affected by temperature $[73,74]$ and have indicated a possible role of humidity [74] and precipitation [70]. In a study to investigate the effect of climate factors on Bluetongue virus infection in a simulated cattle herd, rainfall was identified as the most important factor in determining the prevalence of Bluetongue virus infection [75]. In addition to rainfall, warm temperatures favor vector breeding, but excessive temperatures may reduce the survival of adult vectors [76].

Rift Valley fever, which is transmitted by many different species of insect vectors that have a wide distribution, is increasingly getting global attention [77]. Primarily, the disease affects sheep, cattle and goats and causes high mortality in newborns and abortion in pregnant animals [78]. Besides, the disease affects human as well. Additional economic impacts arise from restrictions on human and animal movement as well as in the trade of animals and animal products [79]. Its occurrence is known to follow periods of widespread and heavy rainfall associated with the development of a strong inter-tropical convergence zone [80]. Elevated and widespread rainfall creates ideal conditions for the flooding of mosquito breeding habitats in east and southern Africa [81]. The flooding of these breeding habitats induces the hatching of infected mosquito eggs that are dormant in the soil, producing infected adult females in 7 - 10 days, which can transmit the Rift Valley fever virus to domestic animals [82]. Climate conditions caused by the El Ninõ/El Nina Southern Oscillation (ENSO) are recognized to be linked with outbreaks of various human and livestock diseases in various countries [83]. Disease outbreaks in Egypt (1977-1978 and 1993), Mauritania (1987), Madagascar (1990-1991), Kenya and Somalia (1997) coincided with exceptionally above normal rainfall [84]. The late 2006 early 2007 outbreak adds to the historical evidence that inter-annual climate variability associated with ENSO has a large influence on Rift Valley fever outbreaks in the Horn of Africa through episodes of abnormally high rainfall [81]. When both equatorial Pacific and Indian Ocean temperatures were elevated, the Indian Ocean temperature rise was indicative of the intensity and the duration of Rift Valley fever activity [85]. These oscillations have also been thought to change rainfall patterns in tropical regions [86].

Climate also plays a vital part in determining the distribution of ticks, which are responsible for diseases such as Theileriosis (East Coast fever), Cowdria ruminantium (Heartwater), Anaplasmosis (Gallsickness), and Babesio- sis (Red Water). Prevalence and intensity of tick infestation have been associated with temperature and humidity. In a study in Pakistan, a mean maximum temperature above $26.8^{\circ} \mathrm{C}$ and mean humidity ranging from $39 \%$ to $65 \%$ were found to be favorable for tick populations [87]. On the other hand, higher altitude and lower temperatures delay the activity of ticks [88]. One of the conesquences of global climate change will be a likely reducetion of biodiversity [89], which may also increase the probability of more ticks feeding on cattle [90] since their natural hosts may disappear.

East Coast fever is one of the most important livestock diseases in Africa [91], and its distribution is directly related to the distribution of the tick, Rhipicephalus appendiculatus. The distribution range of East Coast fever extends south from southern Sudan to eastern South Africa and as far west as the Democratic Republic of the Congo (DRC) [92]. Because of the high morbidity and mortality rate, East Coast fever restrains the economic development of cattle farming in African countries [93]. Apart from direct losses due to cattle mortality, in endemic areas where chronic East Coast fever occurs, other less quantifiable effects of the disease are apparent-including low fertility rates, reduced growth and milk production, paralysis, and secondary attacks from other parasites [94]. Future climate change scenarios may affect the distribution of $R$. appendiculatus. For example, the predicted enhanced rainfall and rise in temperature may be responsible for transforming the Northern and Western Cape Provinces of South Africa as well as Botswana, Zambia and eastern DRC to be climatically suitable places for $R$. appendiculatus. On the other hand, western arid regions of Africa may become climatically unsuitable for $R$. appendiculatus infestation in response to predicted increases in temperature in an already hot and dry area [92].

Heartwater is transmitted by ticks of the genus Amblyomma in Africa. Heartwater is the second mayor tickborne disease after East Coast fever (Theileriosis). Its occurrence spans most of the sub-Saharan African region and the neighbouring islands [95]. In southern Africa it is considered to be the main tick-borne disease and has a significant economic impact on livestock production. Economic losses associated with Heartwater result from the high mortality rate it causes, which ranges between $20 \%$ and $90 \%$, and the reduced productivity it causes in both clinically ill and surviving/recovered animals, which become chronic carriers of the disease [96]. This disease is also reported in the Caribbean (Guadeloupe, MarieGalante and Antigua), from where it threatens the American mainland [84].

There have been no reports of Heartwater in South America, however some researchers point to the possibility of dissemination of this disease on the continent. The possibility for the introduction of Amblyomma varie- 
gatum in Brazil through the northern State of Roraima, which borders with Guyana and Venezuela, has been mentioned; although reports on the presence of this tick in South American countries, such as Guatemala, Venezuela and Guyana, have not been confirmed [97]. However, it has been identified in North America and the Caribbean [98], posing a significant risk of infection of cattle in the region as indigenous competent carrier ticks are present. Its expansion into the South American continent is to be expected in the future. A complicating factor is the occurrence of South American species of the genus Amblyomma that can transmit Heartwater once infected by positive hosts. One of these species, Amblyomma cajannense, has wide distribution in Brazil. It is not known yet whether these species are as efficient at transmitting Heartwater as A. variegatum [97], and concern was expressed about the risk of introduction of this tick in Brazil [99].

\section{NUTRITIONAL VALUE OF PASTURES}

In the tropics and subtropics, natural pastures have both lower nutritional value and lower tiller density than in temperate regions [19]. This is because tropical grasses $\left(\mathrm{C}_{4}\right)$ have developed a different photosynthetic pathway to adapt to the climate. The $\mathrm{C}_{4}$ refers to a 4 carbon compound compared to a 3 carbon compound $\left(\mathrm{C}_{3}\right)$ in temperate grasses. $\mathrm{C}_{4}$ plants have a higher photosynthetic rate, which results in high fibre content, low leaf to stem ratio, reduced digestibility and intake [100]. $\mathrm{C}_{4}$ plants have a competitive advantage over plants with the more common $\mathrm{C}_{3}$ carbon fixation pathway under conditions of drought, high temperatures, and nitrogen or $\mathrm{CO}_{2}$ limitation. When grown in the same environment, at $30^{\circ} \mathrm{C}, \mathrm{C}_{3}$ grasses lose approximately 833 molecules of water per $\mathrm{CO}_{2}$ molecule that is fixed, whereas $\mathrm{C}_{4}$ grasses lose only 277 molecules of water per $\mathrm{CO}_{2}$ molecule fixed. This increased efficiency of water use in $\mathrm{C}_{4}$ grasses means that soil moisture is conserved, allowing them to grow for longer in arid environments [101].

As a result of this phenomenon, the general perception was that $\mathrm{C}_{4}$ grasses may replace $\mathrm{C}_{3}$ grasses as a result of global warming. However, an aspect that was not considered is that $\mathrm{C}_{4}$ plants are very efficient users of $\mathrm{CO}_{2}$ and grow well even at very low $\mathrm{CO}_{2}$ concentrations and that increases in $\mathrm{CO}_{2}$ concentrations may not significantly increase their growth. In contrast, $\mathrm{C}_{3}$ plants are very inefficient users of $\mathrm{CO}_{2}$ and their growth may increase at $\mathrm{CO}_{2}$ levels far above the present. This will also bring about big increases in their efficiency in the use of plant-available water in soils.

Current evidence suggests that the concentrations of atmospheric $\mathrm{CO}_{2}$ predicted for the year 2100 will have major implications for plant physiology and growth. Under elevated $\mathrm{CO}_{2}$ most plant species show higher rates of photosynthesis, increased growth, decreased water use and lowered tissue concentrations of nitrogen and protein. Rising $\mathrm{CO}_{2}$ over the next century is likely to affect natural plant communities. The effects of elevated $\mathrm{CO}_{2}$ are not uniform on plants. Some species, particularly those that utilize the $\mathrm{C}_{4}$ variant of photosynthesis, show less response to elevated $\mathrm{CO}_{2}$ than other types of plants. Rising $\mathrm{CO}_{2}$ concentration is therefore likely to have complex effects on the growth and composition of natural plant communities [102] and may lead to changes in the composition of plant communities, as some species will reap more advantage from the increased $\mathrm{CO}_{2}$ than others. In mixed species experiments under high fertility conditions, $\mathrm{C}_{4}$ plants decrease as a proportion of the biomass of plant communities under elevated $\mathrm{CO}_{2}$. Similarly, under low fertility conditions, legumes increase as a proportion of the biomass of plant communities under elevated $\mathrm{CO}_{2}$ concentrations [103].

The effect of global warming on the quality of pastures in the tropics and subtropics will thus depend whether the global warming is a result of increased $\mathrm{CO}_{2}$ levels or not.

\section{ADAPTATION TO PRODUCTION ENVIRONMENTS}

As a result of global warming, livestock types/strains that are better adapted to higher ambient temperatures, lower nutritional value of the grass in some cases, and expansion of diseases, especially ticks and tick borne diseases in Africa [15], must be promoted and improved in the developing countries of the southern hemisphere. With such challenges, matching genotypes with production environments will become more crucial, requiring the utilization of diverse genetic resources with the appropriate mix of genetic potential for growth, milk production, resistance to diseases and prolificacy [104]. The question is how to measure adaptation and how to select for it.

Adaptability of an animal can be defined as the ability to survive and reproduce within a defined environment [105] or the degree to which an organism, population or species can remain/become adapted to a wide range of environments by physiological or genetic means [106]. An improved understanding of the adaptation of livestock to their production environments is important, but adaptation is complex and thus difficult to measure [15]. Extensive research has been conducted on the direct measurement of adaptation. This included direct measurements on the animal such as rectal body temperature, respiration rate, heart (pulse) rate, sweating rate (water loss), skin thickness and hair per $\mathrm{cm}^{2}$. In addition, more sophisticated measurements investigated include the heat tolerance test where the difference in body temperature is measured before and after exposure to extreme heat, and 
temperature change associated with exercising the animals [22,107-108].

Several proxy-indicators for adaptation are available and have also been used [109]. These include reproductive traits such as fertility, survival, birth rate and perinatal mortality; production traits such as growth rate, milk production, low mortality and longevity; and health traits such as faecal egg counts and number of external parasites [22,107,109-111].

Adaptation can also relate to either resistance or tolerance. Resistance means that animals do not get affected by unfavorable conditions, or they quickly get accustomed to them. Tolerance means that the animals stay affected but continue to live, with or without some degree of discomfort [109,112].

McManus et al. [113,114] discuss the consequences of decisions made in animal breeding and the effect thereof on genetic variability, adaptability and conservation. The conclusion is that a production system approach should be taken when deciding on which breed should be used and decisions taken should be in the context of costbenefit and practical applications. This will allow a more pragmatic look at the use of technology and the evaluation of different production systems. The selection of cattle in Brazil has focused on production [115] while many other countries have also included traits associated with the health and welfare of animals. Both within and between breeds, the maintenance of body temperature is determined by heritable traits such as capacity to perspire, tissue structure as well as skin and coat color [33].

A study that estimated the heritabilities of traits related to heat stress found high heritabilities of $0.75 \pm 0.08$, $0.36 \pm 0.09$ and $0.63 \pm 0.08$ for black spots, hair length and hair diameter respectively [116]. Different genetic groups reacted differently on exposure to solar radiation and drastic temperature changes by changing their behavior and productivity, although they also suffered from changes in various physiological parameters [117]. Some studies comparing tolerance within and between breeds showed that in general the breed has an effect on the tolerance to heat, but that groups of animals within a breed also showed varying tolerance to heat $[7,108,118,119]$. Thus, genetic characteristics play an important role in the tolerance to heat by the animals [34].

The Australian beef industry presents one of the best examples of production systems where adapted zebu breeds are utilized through crossbreeding with taurine cattle, resulting in genotypes and synthetic breeds that cope better with the harsh environments, and which could be used commercially in some of the systems in developing countries. It has been reported that the Australian system is evolving as an efficient tool to improve the productive (meat quality) and reproductive (fertility rates) performance of zebu cattle adapted to the harsh tropical climatic conditions [105]. Similarly, successful dairy and beef programs have been developed in Brazil [120].

Most beef cattle production systems in southern Africa rely only on small capital inputs in all forms (human, natural, physical, financial, social, knowledge, cultural and physiological) [121]. This may be the reason why indigenous breed improvement is still complicated. These breeds also have very high levels of phenotypic variation (personal observation) in medium to poor nutritional environments. Under these circumstances not even conventional genetic ranking procedures will be successful [122].

More than $70 \%$ of beef cattle in South Africa are marketed through the feedlot system. A survey has revealed that $67 \%$ of feedlot cattle are crossbreds, indicating that crossbreeding is playing a significant role in the commercial beef industry [123]. Crossbreeding is used to improve the efficiency of beef production in indigenous Sanga breeds or to increase the adaptability of exotic breeds (usually British and European) quickly. A number of composite breeds has also been developed and are declared landrace breeds [124]. A study with the indigeus Afrikaner breed [125] showed that two-breed crosses (50\% indigenous: $50 \%$ exotic) and three-breed crosses (25\% indigenous: $75 \%$ exotic) increased productivity, especially in cumulative traits such as calf/cow weight ratios, weaning rate and feed conversion ratio under innsive feedlot conditions. In respect of crossbreeding sys$\mathrm{ms}$, innovative systems that involve simplified natural, terminal breeding with either another purebred or comsite sire line on a part of the herd can be used. However, it must be ensured that the indigenous/naturalized cattle are conserved [126].

It is important to note that there are large differences between breeding cattle for the subtropics/tropics and temperate areas, the main difference being in trait definion. Cattle in subtropical and tropical environments are subjected to numerous stress factors [127], e.g.: 1) parates (tick and tick borne diseases, internal parasites, flies); 2) seasonally poor nutrition; 3 ) high temperatures or high daily temperature variation; 4) humidity (both high and low); and 5) temperament which is exaggerated by exnsive production systems. In these cases management interventions may be possible, but they are difficult and expensive to implement, particularly in poorly adapted cattle. The best method of ameliorating the effects of these environmental stress factors to improve productivity and animal welfare is to breed cattle that are adapted and productive in the presence of these stress factors, without the need of managerial interventions.

At the very extreme end of the scale, the ultimate judgment may rest on those individual cows and bulls in a population that survive extreme environmental conditions, such as severe drought. Comprehensive characterization of such individuals at genomic level may provide 
some useful measures of adaptability. Disasters such as extreme droughts can therefore provide opportunities for identifying individuals with the desired adaptive attributes.

\section{FINAL CONSIDERATIONS}

The way animals are bred and farmed changed radically in the twentieth century and the human population explosion gave rise to widespread competition with other species and uses for agricultural land. This also influenced the environment in which animals are raised, with increased intensity of production with changes in production systems, breeds used and eventually climate change. Climate change should be accepted as a reality and planning, research and development should be aimed at resilience and adaptation to the new climates. A mean increase in global surface temperature between $1.8^{\circ} \mathrm{C}$ and $4.0^{\circ} \mathrm{C}$ is expected up to 2100 [128], accompanied by a decrease in yield of $10 \%-20 \%$ to 2050 due to increased temperature and drought [129].

The probable increase in the frequency of heat stress, droughts and floods will have adverse effects on productivity and the development of livestock discomfort indices should receive attention.

The type of production strategy to be followed in the developing countries of the southern hemisphere will depend primarily on the environment and the management level [15]. There is also a need to match the genotype to the environment to ensure a sustainable increase in production [9], with definition of the breeding objectives and adoption of criteria to guide the process more efficiently, aiming at sustainable production in changing environments.

Environmental sustainability is based on knowledge of the processes that control the dynamics of production systems of a given region. The search for sustainability is a constant challenge and this is the main goal for rearchers working in these regions. The redesign of farm management, biodiversity conservation and improving the use of natural resources in a sustainable manner will be possible only with the monitoring of agricultural ecosystems and the use of appropriate technologies. There are many options available aimed at the potential adaptation of existing beef production systems in the face of risks posed by climate change [130]. Science itself will also have to adapt, with multidisciplinary problems requiring multidisciplinary solutions that focus on the integration between the areas of knowledge and a better relationship with decision makers.

\section{REFERENCES}

[1] FAO (2009) Coping with a changing climate: Considerations for adaptation and mitigation in agriculture. http://www.fao.org/docrep/012/i1315e/i1315e00.htm

[2] Environment Agency (2009) Climate change, adapting for tomorrow.

http://publications.environment-agency.gov.uk/pdf/GEH O0709BQBW-e-e.pdf

[3] Gaughan, J.B., et al. (2009) Response of domestic animals to climate challenges. In: Ebi, K.L., Burton, I. and McGregor, G.R., Eds., Biometeorology of Adaptation to Climate Variability and Change, Springer Science, Heidelberg, 131-170.

[4] Nardone, A., Ronchi, B., Lacetera, N., Ranieri, M.S. and Bernabucci, U. (2010) Effects of climate changes on animal production and sustainability of livestock systems. Livestock Science, 130, 57-69. doi:10.1016/j.livsci.2010.02.011

[5] Thornton, P., et al. (2007) Vulnerability, climate change and livestock-Research opportunities and challenges for poverty alleviation. SAT eJournal, 4, 1-23. www.icrisat.org/journal/SpecialProject/sp7.pdf

[6] McManus, C., et al. (2011) Os desafios da produção animal frente às mudanças climáticas. Revista Veterinária e Zootecnia (Unesp), 18, 142-148.

https://uspdigital.usp.br/tycho/producaoacademica/cena/.. .P-0.html

[7] McManus, C., et al. (2009) Heat tolerance in Brazilian sheep: Physiological and blood parameters. Tropical Animal Health and Production, 41, 95-101. doi:10.1007/s11250-008-9162-1

[8] Marai, I.F.M. and Haeeb, A.A.M. (2010) Buffalo's biological functions as affected by heat stress: A review. Livestock Science, 127, 89-109. doi:10.1016/j.livsci.2009.08.001

[9] Gaughan, J.B., Mader, T.L., Holt, S.M. and Lisle, A. (2008) A new heat load index for feedlot cattle. Journal for Animal Science, 86, 226-234. doi:10.2527/jas.2007-0305

[10] Seo, S.N. and Mendelsohn, R. (2008) A structural ricardian analysis of climate change impacts and adaptations in African agriculture. Policy Research Working Paper Series 4603, The World Bank.

https://openknowledge.worldbank.org/bitstream/.../WPS4 603.txt

[11] Wolfe, M.J., et al. (2008) Developments in breeding cereals for organic agriculture. Euphytica, 163, 323-346. doi:10.1007/s10681-008-9690-9

[12] Yahdjian, M.L. and Sala, O.E. (2008) Climate change impacts on South America Rangelands. Rangelands, 34-39. doi:10.2111/1551-501X(2008)30[34:CCIOSA]2.0.CO;2

[13] Department of Environmental Affairs, Republic of South Africa (2010) National climate change response green paper.

http://www.environment.gov.za//Documents/Documents/ 2010Nov17/climate_change_greenpaper.pdf

[14] Romanini, C.E.B., et al. (2008) Impact of global warming on Brazilian beef production. Proceedings of the Congress on Livestock Environment VIII, Iguassu Falls, 31 August-4 September 2008.

http://elibrary.asabe.org/abstract.asp?aid $=25597 \& \mathrm{t}=2 \& \mathrm{re}$ 


\section{dir $=\&$ redirType $=$}

[15] Scholtz, M.M., et al. (2010) Environmental-genotype responses in livestock to global warming: A Southern African perspective. South African Journal of Animal Science, 40, 408-413. http://www.sasas.co.za/journals/2010/5

[16] Herrero, M., Hanotte, O., Notenbaert, A. and Thornton, P.K. (2008) Potential of modelling animal genetic resources data in relation to other existing data sets. In: Pilling, D., Rischkowsky, B. and Scherf, B., Eds., Report on the FAO/WAAP Workshop on Production Environment Descriptors for Animal Genetic Resources Report, Caprarola, 6-8 May 2008.

www.fao.org/docrep/meeting/022/mb386e.pdf

[17] Smit, B., Mc Nabb, D. and Smihers, J. (1996) Agricultural adaptation to climatic variation. Climatic change, 33, 7-29. doi:10.1007/BF00140511

[18] Hulme, P.H. (2005) Adapting to climate change: Is there scope for ecological management in the face of a global threat. Journal of Applied Ecology, 42, 784-794.

[19] Linington, M.J. (1990) The use of Sanga cattle in beef production. In: Technical Communication No 223, Department of Agriculture, South Africa, 31-37. http://www.cabdirect.org/abstracts/19910191726.html;jse ssionid $=68526887 \mathrm{~A} 6768 \mathrm{BEBC} 40915 \mathrm{ECF} 4 \mathrm{C} 67966$

[20] Baccari Jr., F. (2001) Manejo ambiental da vaca leiteira em climas quentes. In: Londrina: Editora da Universidade Estadual de Londrina.

[21] Nardone, A., Ronchi, B., Lacetera, N. and Bernabucci, U. (2006) Climatic effects on productive traits in livestock. Veterinary Research Communications, 30, 75-81. http://dspace.unitus.it/bitstream/2067/139/1/06_Nardone vet_res_com.pdf

[22] Bonsma, J.C. (1983) Man must measure: Livestock production. Agi Books, Cody.

[23] Silva, R.G. (2000) Introducao a bioclimatalogia animal. Sao Paulo

[24] Salles, M.S.V., Zanetti, M.A., Salles, F.A., Titto, E.A.L. and Conti, R.M.C. (2010) Changes in ruminal fermentation and mineral serum levels in animals kept in high temperature environments. Revista Brasileira de Zootecnia, 39, 883-890. doi:10.1590/S1516-35982010000400025

[25] Bernabucci, U., et al. (2010) Metabolic and hormonal acclimation to heat stress in domesticated ruminants. Animal, 4, 1167-1183. doi:10.1017/S175173111000090X

[26] Nääs, I.A. (1989) Princípios de conforto térmico na produção animal. Ícone, São Paulo.

[27] Berman, A., et al. (1985) Upper critical temperatures and forced ventilation effects for high yielding dairy cows in a subtropical climate. Journal of Dairy Science, 68, 14881495. doi:10.3168/jds.S0022-0302(85)80987-5

[28] Hahn, G.L. (1999) Dynamic responses of cattle to thermal heat load. Journal of Animal Science, 77, 10-20. www.animal-science.org/content/77/suppl_2/10.full.pdf

[29] West, J.W. (1999) Nutritional strategies for managing the heat stressed dairy cow. Journal of Animal Science, 77,
21-35.

http://www.journalofdairyscience.org/article/S0022-0302( 10)00717-4/references

[30] Kadzere, C.T., Murphy, M.R., Silanikove, N. and Maltz, E. (2002) Heat stress in lactating dairy cows: A review. Livestock Production Science, 77, 59-91. doi:10.1016/S0301-6226(01)00330-X

[31] Silanikove, N., Shapiro, F. and Shinder, D. (2009) Acute heat stress brings down milk secretion in dairy cows by up-regulating the activity of the milk-borne negative feedback regulatory system. BMC Physiology, 9, 13. http://www.biomedcentral.com/1472-6793/9/13

[32] Morrison, S.R. (1983) Ruminant heat stress: Effect on production and means of alleviation. Journal of Animal Science, 57, 1594-1600.

http://europepmc.org/abstract/MED/6370944/reload=0;js essionid=FPaI4g4WLkzldnQDzLu4.8

[33] Finch, V.A. (1986) Body temperature in beef cattle: Its control and relevance to production in the tropics. Journal of Animal Science, 62, 531-542.

http://journalofanimalscience.org/content/62/2/531.full.pd $\underline{\mathrm{f}+\mathrm{html}}$

[34] Du Preez, J.H. (2000) Parameters for the determination and evaluation of heat stress in dairy cattle in South Africa. Journal of Veterinary Research, 67, 263-271. http://www.ncbi.nlm.nih.gov/pubmed/11206394

[35] Thatcher, W.W., Flamenbaum, I., Block, J. and Bilby, T.R. (2010) Interrelationships of heat stress and reproduction in lactating dairy cows. Proceedings of High Plains Dairy Conference 2010, 45-60.

www.camposecarrer.com.br/.../2042010-085508-pfizer--novos-enf

[36] Marai, I.F.M., El-Darawany, A.A., Fadiel, A. and AbdelHafez, M.A.M. (2007) Physiological traits as affected by heat stress in sheep-A review. Small Ruminant Research, 71, 1-12. doi:10.1016/j.smallrumres.2006.10.003

[37] McDowell, R.E. (1972) Improvement of livestock production in warm climates. W. H. Freeman \& Company, San Francisco.

[38] West, J.W. (1994) Interactions of energy and bovine somatotropin with heat stress. Journal of Dairy Science, 77, 2091-2102. doi:10.3168/jds.S0022-0302(94)77152-6

[39] Collier, R.J., Beede, D.K., Thatcher, W.W., Israel, L.A., and Wilcox, C.J. (1982) Influences of environment and its modification on dairy animal health and production. Journal of Dairy Science, 65, 2213-2227. doi: $10.3168 /$ jds.S0022-0302(82)82484-3

[40] St-Pierre, N.R., Cobanov, B. and Schnitkey, G. (2003) Economic losses from heat stress by US livestock industries. Journal of Dairy Science, 86, E52-E77.

http://www.sciencedirect.com/science/article/pii/S002203 $\underline{0203740405}$

[41] Folman, Y., Rosenberg, M., Ascarelli, I., Kaim, M. and Herz, Z. (1983) The effect of dietary and climatic factors on fertility, and on plasma progesterone and oestradiol-17 beta levels in dairy cows. Journal of Steroid Biochemistry, 19, 863-868. doi:10.1016/0022-4731(83)90025-0

[42] Ax, R.L., Gilbert, G.R. and Shook, G.E. (1987) Sperm in 
poor quality semen from bulls during heat stress have a lower affinity for binding hydrogen-3 heparin. Journal of Dairy Science, 70, 195-200. doi:10.3168/jds.S0022-0302(87)79994-9

[43] Gwazdauskas, F.C. (1985) Effects of climate on reproduction in cattle. Journal of Dairy Science, 68, 15681578. doi:10.3168/jds.S0022-0302(85)80995-4

[44] Lucy, M.C. (2002) Reproductive loss in farm animals during heat stress. Proceedings of the 15th American Meteorological Society Biological Systems, 50-53. www.ansci.wisc.edu/jjp1/ansci_repro/.../heatstress/referen ces.html

[45] Ricardo, C., et al. (2004) Factors affecting conception rate after artificial insemination and pregnancy loss in lactating dairy cows. Animal Reproduction Science, 84, 239-255. doi:10.1016/j.anireprosci.2003.12.012

[46] Meyerhoeffer, D.C., Wettemann, R.P., Coleman, S.W. and Wells, M.E. (1985) Reproductive criteria of beef bulls during and after exposure to increased ambient temperature. Journal of Animal Science, 60, 352-357. http://www.journalofanimalscience.org/content/60/2/352.1 ong

[47] Howard, J. (2012) Genetic components of fitness and adaptation: Body temperature regulation. www.bifconference.com/bif2012/...pdf.12

[48] Frisch, J.E. and Vercoe, J.E. (1984) An analysis of growth of different cattle genotypes reared in different environments. Journal of Agricultural Sciences, 103, 137-153. doi:10.1017/S0021859600043409

[49] Koger, M.W., Burns, C., Pahnish, O.F. and Butts, W.T. (1979) Genotype by environment interaction in Hereford cattle: I. Reproductive traits. Journal of Animal Science, 49, 396-402. http://agris.fao.org/openagris/search.do?recordID=US198 00540896

[50] Vercoe, J.E. and Frisch, J.E. (1992) Genotype (breed) and environment interaction with particular reference to cattle in the tropics: A review. Asian-Australian Journal of Animal Science, 5, 401-409.

[51] Barlow, R. (1981) Experimental evidence for interaction between heterosis and environment in animals. Animal Breeding Abstracts, 49, 715-737.

[52] Burrow, H.M. (2006) Utilization of diverse breed resources for tropical beef production. Proceedings of the 8th World Congress on Genetics Applied to Livestock Production, Belo Horizonte. www.wcgalp8.org.br/wcgalp8/articles

[53] Burrow, H.M., Griffith, G.R., Barwick, S.A. and Holmes, W.E. (2003) Where to from Brahmans in the Northern Australian herd? Maintaining the economic benefit of earlier infusions of Bos indicus. Proceedings of the Association for the Advancement of Animal Breeding and Genetics, 15, 294-297.

www.csiro.au/ /.../RockhamptonBook_CLI_pdf $\% 20$ Stan dard.pdf

[54] Prayaga, K.C. (2003) Evaluation of beef cattle genotypes and estimation of direct and maternal genetic effects in a tropical environment. 1. Growth traits. Australian Journal of Agricultural Research, 54, 1013-1025. doi:10.1071/AR03071

[55] Jenkinson, D.M. and Mabon, R.M. (1973) The effects of temperature and humidity on skin surface $\mathrm{pH}$ and the ionic composition of skin secretions in Ayrshire cattle. British Veterinary Journal, 129, 282-295.

http://www.researchgate.net/publication/18440695 The e ffect of temperature and humidity on skin surface $\mathrm{pH}$ and the ionic composition of skin secretions in Ayrs hire cattle

[56] Kume, S., Takahashi, S., Kurihara, M. and Aii, T. (1989) Effect of hot environment on $\mathrm{Ca}$ and $\mathrm{P}$ metabolism in dairy cow. Asian-Australian Journal of Animal Science, 2, 259-260.

[57] Hersom, M.J., Hansen, G.R. and Arthington, J.D. (2010) Effect of dietary cation-anion difference on measures of acid.base physiology and performance in beef cattle. Journal of Animal Science, 88, 374-382. doi:10.2527/jas.2009-1925

[58] Ross, J.G., Spears, J.W. and Garlich, J.D. (1994) Dietary electrolyte balance effects on performance and metabolic characteristics in finishing steers. Journal of Animal Science, 72, 1600-1607. www.journalofanimalscience.org/content/72/6/1600.full.p df

[59] Escobosa, A., Coppock, C.E., Rowe, L.D., Jenkins, W.L. and Gates, C.E. (1984) Effects of dietary sodium bicarbonate and calcium chloride on physiological responses of lactating dairy cows in hot weather. Journal of Dairy Science, 67, 574-584. doi:10.3168/jds.S0022-0302(84)81341-7

[60] Schneider, P.L., Beede, D.K. and Wilcox, C.J. (1985) Responses of lactating cows to dietary sodium source and quantity and potassium quantity during heat stress. Journal of Dairy Science, 69, 99-110. doi:10.3168/jds.S0022-0302(86)80374-5

[61] Wang, J.P., et al. (2010) Effect of saturated fatty acid supplementation on production and metabolism indices in heat-stressed mid-lactation dairy cows. Journal of Dairy Science, 93, 4121-4127. doi:10.3168/jds.2009-2635

[62] Luna-Nevarez, P., et al. (2010) Growth characteristics, reproductive performance, and evaluation of their associative relationships in Brangus cattle managed in a Chihuahuan Desert production system. Journal of Animal Science, 88, 1891-1904. doi:10.2527/jas.2009-2541

[63] Kattnig, R.M., Winder, J.A., Wallace, J.D. and Bailey, C.C. (1993) Evaluation of biological efficiency of freegrazing beef cows under semi dessert conditions. Journal of Animal Science, 71, 2601-2607. www.animal-science.org/content/71/10/2601.full.pdf

[64] McManus, C., et al. (2009) Heat tolerance in naturalized Brazilian cattle breeds. Livestock Science, 120, 256-264. doi:10.1016/j.livsci.2008.07.014

[65] Summers, B.A. (2009) Climate change and animal disease. Veterinary Pathology, 46, 1185-1186. doi:10.1354/vp.09-VP-0139-S-COM

[66] Tabachnick, W.J. (2010) Challenges in predicting climate 
and environmental effects on vector-borne disease episystems in a changing world. Journal of Experimental Biology, 213, 946-954. doi:10.1242/jeb.037564

[67] OIE (2008) Report of the Meeting of the OIE Scientific Commission for Animal Diseases. http://www.oie.int/downld/SC/2008/A_SCAD feb2008.p df

[68] Calistri, P., et al. (2004) Bluetongue in Italy: Part I. Veterinaria Italaliana, 40, 243-251. http://www.ncbi.nlm.nih.gov/pubmed/20419672

[69] Wilson, W.C., Mecham, J.O., Schmidtmann, E., Jimenezsanchez, C., Herrero M. and Lager, I. (2009) Current status of bluetongue virus in the Americas. http://ddr.nal.usda.gov/dspace/bitstream/10113/23231/1/I ND44152599.pdf

[70] Wilson, A. and Mellor, P. (2008) Bluetongue in Europe: Vectors, epidemiology and climate change. Parasitology Research, 103, 69-77. doi:10.1007/s00436-008-1053-X

[71] Purse, B.V., Brown, H.E., Harrup, L., Mertens, P.P. and Rogers, D.J. (2008) Invasion of bluetongue and other orbivirus infections into Europe: The role of biological and climatic processes. Revue Scientifique et Technique, 27, 427-442. http://www.oie.int/doc/ged/D5503.PDF

[72] Mellor, P.S. and Wittmann E.J. (2002) Bluetongue virus in the Mediterranean basin 1998-2001. Veterinary Journal, 164, 20-37. doi:10.1053/tvj1.2002.0713

[73] Gerry, A.C. and Mullens, B.A. (2000) Seasonal abundance and survivorship of Culicoides sonorensis (Diptera: Ceratopogonidae) at a southern California dairy, with reference to potential bluetongue virus transmission and persistence. Journal of Medical Entomology, 37, 675-688. doi:10.1603/0022-2585-37.5.675

[74] Wittmann, E.J., Mellor, P.S. and Baylis, M. (2002) Effect of temperature on the transmission of orbiviruses by the biting midge, Culicoides sonorensis. Medical and Veterinary Entomology, 16, 147-156. doi:10.1046/j.1365-2915.2002.00357.x

[75] Ward, M.P. and Carpenter, T.E. (1996) Simulation modeling of the effect of factors on bluetongue virus infection in cattle herds. II. Model experimentation. Preventative Veterinary Medicine, 27, 13-22. doi:10.1016/0167-5877(95)00567-6

[76] St George, T.D. (1985) Epidemiology of bluetongue in Australia: The vertebrate hosts. In: Barber, T.L. and Jochim, M.M., Eds., Bluetongue and Related Orbiviruses, Alan R. Liss, New York, 519-525.

[77] Gubler, D.J. (2002) The global emergence/resurgence of arboviral diseases as public health problems. Archives of Medical Research, 33, 330-342.

http://www.arcmedres.com/article/S0188-4409(02)003788/abstract

[78] Anyamba, A., Linthicum, K.J. and Tucker, C.J. (2001) Climate-disease connections: Rift Valley fever in Kenya. Cadernos de Saúde Pública, 17, 133-140. http://www.scielosp.org/pdf/csp/v17s0/3889.pdf

[79] Cêtre-Sossah, C., et al. (2009) Evaluation of a commercial competitive ELISA for the detection of antibodies to Rift Valley fever virus in sera of domestic ruminants in
France. Preventative Veterinary Medicine, 90, 146-149. http://www.sciencedirect.com/science/article/pii/S016758 7709000774

[80] Anyamba, A., et al. (2009) Prediction of a Rift Valley fever outbreak. Proceedings of the National Academy of Science USA, 106, 955-959.

www.pnas.org/content/106/3/955.full

[81] Davies, F.G., Linthicum, K.J. and James, A.D. (1985) Rainfall and epizootic Rift Valley fever. Bulletin of the World Health Organization, 63, 941-943.

[82] Linthicum, K.J., Bailey, C.L., Davies, F.G. and Tucker, C.J. (1987) Detection of Rift Valley fever viral activity in Kenya by satellite remote sensing imagery. Science, 235, 1656-1659.

http://www.sciencemag.org/content/235/4796/1656.long

[83] Glantz, M.H. (1991) Introduction. In: Glantz, M.H., Katz, R.W. and Nicholls, N., Eds., Teleconnections Linking World Wide Climate Anomalies: Scientific Basis and Societal Impact, Cambridge University Press, New York, 112.

[84] OIE (2009) Rift Valley fever. Technical Disease Cards, 2. www.oie.int/fileadmin/.../RIFT_VALLEY_FEVER_FIN AL.pdf

[85] Linthicum, K.J., et al. (1999) Climate and satellite indicators to forecast Rift Valley fever epidemics in Kenya. Science, 285, 397-400. http://www.sciencemag.org/content/285/5426/397.long

[86] Molion, L.C.B. and Toledo, M.R. (1994) Seca de 1992/93 em Alagoas. Proceedings of the VIII Congresso de Meteorologia. www.cbmet.com/.../22-dfa4c3643abd78c04a2fe9

[87] Sajid, S.M., Iqbal, Z., Khan, M.N., Muhammad, G. and Khan, M.K. (2009) Prevalence and associated risk factors for bovine tick infestation in two districts of lower Punjab, Pakistan. Preventative Veterinary Medicine, 92, 386-391. http://www.sciencedirect.com/science/article/pii/S016758 $\underline{7709002554}$

[88] Jouda, F., Perret, J. and Gern, L. (2004) Ixodes ricinus density, and distribution and prevalence of Borrelia burgdorferi sensu lato infection along an altitudinal gradient. Journal of Medical Entomology, 41, 162-169. http://www.bioone.org/doi/full/10.1603/0022-2585-41.2.1 $\underline{62}$

[89] Cassis, G. (1998) Biodiversity loss: A human health issue. Medical Journal of Australia, 169, 568-569. www.unboundmedicine.com/.../Biodiversity loss:_a hu man health

[90] Olwoch, J.M., Reyers, B. and van Jaarsveldt, A.S. (2009) Host-parasite distribution patterns under simulated climate: Implications for tick-borne diseases. International Journal of Climatology, 29, 993-1000. http://onlinelibrary.wiley.com/doi/10.1002/joc.1801/pdf

[91] Muraguri, G.R., Kiara, H.K. and McHardy, N. (1999) Treatment of east coast fever: A comparison of parvaquone and buparvaquone. Veterinary Parasitology, 87, 25-37.

http://www.sciencedirect.com/science/article/pii/S030440 1799001545 
[92] Olwoch, J.M., Reyers, B., Engelbrecht, F.A. and Erasmus, B.F.N. (2008) Climate change and the tick-borne disease, Theileriosis (East Coast fever) in sub-Saharan Africa. Journal of Arid Environments, 72, 108-120. http://www.ehrn.co.za/publications/download/33.pdf

[93] Schetters, T.P.M., Arts, G., Niessen, R. and Schaap, D. (2010) Development of a new score to estimate clinical east coast fever in experimentally infected cattle. Veterinary Parasitology, 167, 255-259.

http://www.sciencedirect.com/science/article/pii/S030440 1709005603

[94] Pegram, R.G., Lemche, J. and Chizyuka, H.G.B. (1989) Effect of tick control on live weight gain of cattle in central Zambia. Medical and Veterinary Entomology, 3, 313320.

http://onlinelibrary.wiley.com/doi/10.1111/j.1365-2915.19 $\underline{89 . t b 00234 . x / p d f}$

[95] Uilenberg, G. (1983) Heartwater (Cowdria ruminantium infection): Current status. Advances in Veterinary Science and Comparative Medicine, 27, 427-480.

www.upei.ca/ cavepm/.../O'Callaghan $\% 2520$ et $\% 2520 \mathrm{al}$ $\% 25201998$

[96] Uilenberg, G. (1990) Present and future possibilities for the control of cowdriosis and anaplasmosis. Veterinary Quarterly, 12, 39-45.

www.researchgate.net/.../20973835_Present_and_future possibilities

[97] Horner, M.R. (1990) Amblyomma variegatum-Um novo carrapato para a América do Sul? Technical Communication.

http://www.cnpgc.embrapa.br/publicacoes/cot/COT36.ht $\underline{\mathrm{ml}}$

[98] Robinson, J.B., et al. (2009) New approaches to detection and Identification of Rickettsia africae and Ehrlichia ruminantium in Amblyomma variegatum (acari: ixodidae) ticks from the Caribbean. Journal of Medical Entomology, 46, 942-951. doi:10.1603/033.046.0429

[99] Leite, R.C., Faccini, J.L.H. and Granger, S.A. (2001) Occurrence of ticks in cattle in the state of Roraima, northern Brazil. Revista Brasileira de Parasitologia Veterinária, 10, 49-50. http://www.ufrrj.br/rbpv/1012001/c10149 50.pdf

[100] Leng, R.A. (1984) Supplementation of tropical and subtropical pastures for ruminant production. In: Gilchrist, F.M.C. and Macki, R.I., Eds., Herbivore Nutrition in the Tropics and Subtropics, 129-144. http://www.cabdirect.org/abstracts/19861486176.html

[101] Sage, R. and Monson, R. (1999) C4 plant biology. http://books.google.com/?id=H7Wv9ZImW-QC\&pg=PA $\underline{228}$

[102] Taub, D. (2010) Effects of rising atmospheric concentrations of carbon dioxide on plants. Nature Education Knowledge, 3, 21.

http://www.nature.com/scitable/knowledge/library/effects -of-rising-atmospheric-concentrations-of-carbon-1325410 $\underline{8}$

[103] Poorter, H. and Navas, M.L. (2003) Plant growth and competition at elevated $\mathrm{CO}_{2}$ : On winners, losers and functional groups. New Phytologist, 157, 175-198. doi:10.1046/j.1469-8137.2003.00680.x

[104] Blackburn, H. and Mezzadra, C. (2006) Policies for the management of animal genetic resources. Proceedings of the 8th World Congress on Genetics Applied to Livestock Production. Belo Horizonte. www.wcgalp8.org.br/wcgalp8/articles

[105] Prayaga, K.C. and Henshall, J.M., (2005) Adaptability in tropical beef cattle: Genetic parameters of growth, adaptive and temperament traits in a crossbred population. Australian Journal of Experimental Agriculture, 45, 971983. doi:10.1071/EA05045

[106] Barker, J.S.F. (2009) Defining fitness in natural and domesticated population. In adaptation and fitness in animal populations. In: van der Werf, J.H.J., Graser, H.-U., Frankham, R. and Gondoro, C., Eds., Evolutionary and Breeding Perspectives on Genetic Resource Management, Springer, Amsterdam.

[107] Bonsma, J.C. (1980) Livestock production: A global approach. Tafelberg Publishers, Cape Town.

[108] McManus, C., et al. (2009) Heat tolerance in naturalized Brazilian cattle breeds. Livestock Science, 120, 256-264. doi:10.1016/j.livsci.2008.07.014

[109] McManus, C., Louvandini, H. and Paiva S. (2008) Examples of different aspects of adaptive fitness, how they can be measured and possible proxi-indicators. In: Pilling, D. Rischkowsky, B. and Scherf, B., Eds., Report on the FAO/ WAAP Workshop on Production Environment Descriptors for Animal Genetic Resources Report, Caprarola, 6-8 May 2008.

[110] Spickett, A.M., de Klerk, D., Enslin, C.B. and Scholtz, M.M. (1989) Resistance of nguni, bonsmara and hereford cattle to ticks in a bushveld region of South Africa. Onderstepoort Journal of Veterinary Research, 56, 245-251. www.ncbi.nlm.nih.gov/pubmed/2626263

[111] Scholtz, M.M., Spickett, A.M., Lombard, P.E. and Enslin, C.B. (1991) The effect of tick infestation on the productivity of cows of three breeds of cattle. Onderstepoort Journal of Veterinary Research, 58, 71-74. www.ncbi.nlm.nih.gov/pubmed/1881659

[112] Raberg, 1., Sim, D. and Read, A.F. (2007) Disentangling genetic variation for resistance and tolerance to infectious diseases in animals. Science, 318, 812-814.

http://ac-repo-live7.is.ed.ac.uk/bitstream/1842/2140/1/Ra berg $\% 20$ text $\% 20$ figs $\% 20$ SOM.pdf

[113] McManus, C., Cobuci, J., Braccini Neto, J. and Paiva, S.R. (2011) Decision making in animal breeding programs and their consequences for animal production. Revista Brassileira de Reprodução Animal, 35, 69-76. http://www.cbra.org.br/pages/publicacoes/rbra/v35n2/RB 358\%20McManus\%20pag69-76.pdf

[114] McManus, C., et al. (2011) The challenge of sheep farming in the tropics: Aspects related to heat tolerance. Brazilian Journal of Animal Science, 40, 107-120. www.sbz.org.br/revista/artigos/66266.pdf

[115] Verneque, R.S., et al. (2011) Melhoramento genético de gado de leite no Brasil, sociedade Brasileira de melhoramento animal.

http://sbmaonline.org.br/anais/viii/palestras/pdfs/7.pdf 
[116] Bertipaglia, E.C.A., Silva, R.G., Cardoso, V. and Maia, A.S.C. (2007) Estimativas de parâmetros genéticos e fenotípicos de características do pelame e de desempenho reprodutivo de vacas holandesas em clima tropical. Revista Brasileira de Zootecnia, 36, 350-359. doi:10.1590/S1516-35982007000200011

[117] Roberto, J.V.B., Souza, B.B., Silva, A.L.N., Justiano, S.V. and Freitas, M.M.S. (2010) Parâmetros hematológicos de caprinos de corte submetidos a diferentes níveis de suplementação no Semi-Árido Paraibano. Revista Caatinga, 23, 127-132.

[118] McManus, C. and Miranda, R.M. (1997) Comparação das raças de ovinos santa inês e bergamácia no distrito federal. Revista Brasileira de Zootecnia, 26, 627-636.

[119] Quesada, M., McManus, C., Couto, F.A. and Araújo, D. (2001) Tolerância ao calor de duas raças de ovinos deslanados no Distrito Federal. Revista Brasileira de Zootecnia, 30, 1021-1026.

[120] Madalena, F.E. (2005) Considerations on the management of animal genetic resources in Latin America. EAAP/SLU/FAO/ICAR Workshop on Sustainable Management of Animal Genetic Resources: Linking Perspectives globally, Uppsala, 2 June 2005.

[121] Scholtz, M.M., Nengovhela, N.B., McManus, C., Theunissen, A and Okeyo, A.M. (2012) Political, economical and social challenges for beef production in Southern Africa. In: Developing Countries: Political, Economic and Social Issues, Nova Science Publishers Inc., Hauppauge, New York, (In press).

[122] Timon, V.M. (1993) Strategies for sustainable development of agriculture-An FAO perspective. http://www.fao.org/docrep/004/T0582E/T0582E05.htm
[123] Scholtz, M.M., Bester, J., Mamabolo, J.M. and Ramsay, K.A. (2008) Results of the national survey undertaken in South Africa with emphasis on beef. Applied Animal Husbandry and Rural Development, 1, 1-9. www.sasas.co.za/aahrd/1193

[124] Scholtz, M.M. (2011) Beef breeding in South Africa. 2nd Edition, ARC, Pretoria.

[125] Theunissen, A. (2011) Characterization of breed additive and heterosis effect in beef cattle using experimental results. M.Sc. Thesis, University of the Free State, Bloemfontein.

[126] Scholtz, M.M. and Theunissen, A. (2010) The use of indigenous cattle in terminal crossbreeding to improve beef cattle in Sub-Saharan Africa. Animal Genetic Resources, 46, 33-36.

[127] Prayaga, K.C., Barendse, W. and Burrow, H.M. (2006) Genetics of tropical adaptation. Proceedings of the 8th World Congress on Genettics Applied to Livestock Production. Belo Horizonte. www.wcgalp8.org.br/wcgalp8/articles

[128] IPCC (2011) Climate change: Impacts, adaptation and vulnerability. Summary for policy makers. http://www.ipcc.cg/SPM13ap07.pdf

[129] Jones, P.G. and Thornton, P.K. (2003) The potential impacts of climate change in tropical agriculture: The case of maize in Africa and Latin America in 2055. Global and Environmental Change, 13, 51-59. doi:10.1016/S0959-3780(02)00090-0

[130] Howden, S.M., et al. (2007) Adapting agriculture to climate change. Proceedings of the National Academy of Science, 104, 19691-19696. doi:10.1073/pnas.0701890104 